\title{
Age re-assessment of the cave bear assemblage from Urşilor Cave, north-western Romania
}

\author{
Marius Robu \\ "Emil Racoviță" Institute of Speleology, Romanian Academy, Calea 13 Septembrie, 13, 050711, Bucharest, Romania
}

\begin{abstract}
The most common methods used for assessing the relative age of a cave bear bone assemblage are the $\mathrm{P}^{4} / 4$ index (morphodynamic index of the cave bear fourth premolar), the K-index, and the Index of Plumpness (both used for cave bear's $2^{\text {nd }}$ metatarsal). Preliminary work on these indexes, for Urşilor Cave (NW Romania), has indicated one of the youngest European cave bear populations. As the number of extracted fossil bones from the palaeontological excavation increased recently, a re-assessment of the of the age of the cave bear assemblage is necessary. 206 cave bear fourth lower and upper premolars and 587 metapodials were analyzed. The $\mathrm{P}^{4} / 4$ morphodynamic index, the $\mathrm{K}$-index and the Index of Plumpness were calculated for the local MIS 3 cave bear bone assemblage. The results of the three indices have lower values when compared with the previously obtained for the same site and respect the subsequent radiometric ages (ca. 47-39 ky BP). However, the results for $\mathrm{P}^{4} / 4$ morphodynamic index, $\mathrm{K}$-index, and Index of Plumpness are of lesser relevance when used to assess the relative age of MIS 3 cave bear bone assemblages. All three methods require caution when applied and interpreted on short time intervals and on smaller geographic areas.
\end{abstract}

Keywords: Ursus spelaeus, biochronology, $\mathrm{P}^{4} / 4$ morphodynamic index, K-index, Urşilor Cave, Upper Pleistocene, Romanian Carpathians

Received 16 August 2015; Revised 15 April 2016; Accepted 21 April 2016

Citation: Robu M., 2016. Age re-assessment of the cave bear assemblage from Urşilor Cave, northwestern Romania. International Journal of Speleology, 45 (2), 123-133. Tampa, FL (USA) ISSN 0392-6672 http://dx.doi.org/10.5038/1827-806X.45.2.1947

\section{INTRODUCTION}

The biochronology of fossil species is used for assessing the relative age of a bone assemblage. At the end of the 1980s and 1990s, Rabeder (1989, 1999) developed a biochronological index for cave bear assemblages, based on the evolutionary trend of the fourth premolars $\left(\mathrm{P}^{4} / 4\right.$ index). This method can be applied when there is no radiometric age control for the fossils. The main issue with the morphodynamic index of the Marine Isotopic Stage 3 [MIS 3 (5924 ky BP - Pettitt \& White, 2012)] cave bear bone assemblages is that the method has standard errors that are too large when compared with the length of this period. Nonetheless, the obtained $\mathrm{P}^{4} / 4$ indices, plotted together with the results recorded for other sites, may provide a general time frame for the evolutionary level of a given cave bear population.

Another biochronological proxy often used in the cave bear research is the $\mathrm{K}$-index. The $\mathrm{K}$-index of the $2^{\text {nd }}$ metatarsal is a suitable indicator of the evolutionary stage of a cave bear population, from the postcranial skeleton (Withalm, 2004). As older cave bear fauna shows lower K-index values when compared with those from younger strata and this method shows a significant correlation with the radiometric scale, it represents a biochronological proxy for the age of cave bear bone assemblages (Withalm, 2001).

The Index of Plumpness (= robustness; Ip), applied on metapodials, is used as well for biochronological purposes. It has been shown that towards cave bears' extinction, Ip values increased as the metapodials became more robust (Withalm, 2001). As in the case of $\mathrm{K}$-index, the most biochronologically relevant are the measurements on the $2^{\text {nd }}$ metatarsals, since this bone seems to be less affected by the sexual dimorphism or by the ontogenetic variability like the other metapodials (Withalm, 2004).

For central and western European cave bear sites morphological studies based on dental features (Rabeder, 1995) that later were confirmed by molecular results (Hofreiter et al., 2004), proposed two distinct species within the European MIS 3 cave bear group: $U$. spelaeus and $U$. ingressus (Rabeder et al., 2004). The first species corresponds to the western clade of the group, while the second species 
has a Central and Eastern European distribution. They separated between $414 \mathrm{ky}$ BP and $173 \mathrm{ky}$ BP according to molecular dating (Knapp et al., 2009; Baca et al., 2012). Two other additional MIS 3 cave bear subspecies were also identified in Alps: Ursus s. ladinicus and Ursus s. eremus (Rabeder et al., 2004a, 2006). From the Romanian Carpathians, the study on the phylogeny of the Oase Cave bears (Richards et al., 2008), based on an analysis of the morphology and mtDNA control region of 19 samples, found that the examined material shows clear affinity to populations from southern Germany, Austria, Croatia, and Slovakia (U. ingressus haplogroup). Other sites from the Romanian Carpathians (e.g., Urşilor, Cioclovina, Muierilor caves) with similar age of the cave bear thanatocoenosis and similar values of the $\mathrm{P}^{4} /{ }_{4}$ index are susceptible of hosting the same fossil species (unpubl. material).

Urşilor (Bears) Cave is one of the most famous MIS 3 cave bear European sites and it includes a complete range of evidence belonging to this species: a full range of bioglyphs (nests, footprints, scratch marks, etc.) and several bone assemblages of different genesis throughout the cave system (in situ thanatocoenosis, reworked thanatocoenosis or mixed thanatocoenosis; Constantin et al., 2014; Robu, 2015, 2016b).

As the new excavation campaigns from the scientific reserve of the cave (lower level) brought out more cave bear bones and new results on direct dating (AMS ${ }^{14} \mathrm{C}$ dating) on fossil bones were recently obtained (Constantin et al., 2014), a re-assessment of the biochronology of the excavated bone assemblage was needed. Moreover, although Romania has a high density of MIS 3 bone deposits, only two previous cave bear sites were analyzed thoroughly: Oase (Quilès et al., 2006) and Cioclovina (Petrea, 2009) caves. Therefore, the results obtained at Urssilor Cave, along with the other two sites, on biochronology corroborated with the new radiocarbon data, will enhance understanding of MIS 3 cave bears from the Romanian Carpathians.

\section{THE SITE}

Urşilor Cave is situated the nortwestern part of the Romanian Carpathians (Fig. 1A), its geological, geomorphological, and sedimentological background being discussed in detail in Constantin et al. (2014). The extracted fossil material was originally located at the lower level of the cave (= Scientific Reserve), in the Excavation Chamber and it derives from an in situ thanatocoenosis (Jurcsák et al., 1981; Robu et al., 2011; Robu, 2015, 2016a). The palaeontological excavation extends over an area of $c .9 \mathrm{~m}^{2}$ and has a current depth of c. $2.3 \mathrm{~m}$, without reaching the bedrock (Fig. 1B). Eight distinct sediment layers (labeled L I-VIII) were identified: L I-III, and L VIII are rich in cave bear remains, while the remaining layers are sterile. The bone beds extend across the whole section, while the lower sterile ones were found to be thicker along the A1-D1 transect and become thinner towards the D4 square, where they lie over a flowstone terrace (Fig. 1B) (Constantin et al., 2014; Robu, 2015).
The biochronological results obtained from Urşilor Cave were compared with the available data from the cave bear sites across Europe: Ukraine, Macedonia, Italy, Slovenia, Austria, France, Croatia, Slovakia, Germany, and Romania (Fig. 1A; Table 1).

\section{MATERIALS AND METHODS}

A morphodynamic investigation of the upper (P4) and lower fourth premolars (p4) was carried out, applying the method developed by Rabeder (1989, 1999) and Rabeder \& Tsoukala (1990), on 206 specimens $(N=206)$, ranging from juveniles to adults, from the palaeontological excavation within Urşilor Cave (103 specimens of P4 and 103 specimens of p4). This method is based on the evolutionary trend in the occlusal plan for the fourth premolars and has been discussed in Robu et al. (2011).

Almost 590 cave bear metapodials $(N=587)$ from the palaeontological excavation were investigated, out of which 338 were metacarpals and 249 were metatarsals. The osteometric measurements were performed following the methodology proposed by Tsoukala and Grandal D'Anglade (2002), using a $150 \mathrm{~mm}$ electronic caliper ( $\pm 0.01 \mathrm{~mm}$ accuracy). As in Robu et al. (2011), K-index was erroneously used (focusing on the $4^{\text {th }}$ metatarsal), now the use of K-index (equations 1 and 2; Fig. 2) has emphasized the evolutionary relevance of the $2^{\text {nd }}$ metatarsal bone $(N=44)$; the method proposed by Gužvica \& RadanovićGužvica (2000) and the Index of Plumpness (equations 3 and 4) were previously presented in detail in Robu et al. (2011). The measurements and the equations used for the calculation of both indices are shown in Fig. 2. For the equation [1], DTprox represents the proximal breadth, DAPprox, the proximal height, and $L$ is the greatest length (= maximum length). The standardization of the obtained K-index [2] was made with the MIS 3 cave bear population from Gamssulzen Cave (K-index = 5.63; Withalm, 2004). The Index of Plumpness was calculated according to Withalm (2001). For the equation [3], DTdist is the distal breadth and $L$, the greatest length. The standardization was made with the MIS 3 cave bear population from Gamssulzen Cave (Withalm, 2001) and the equation used was [4].

The values obtained from Urşilor Cave for the $\mathrm{P}^{4} / 4$ index, $\mathrm{K}$-index, and Index of Plumpness were correlated with the radiometric scale and were plotted with other similar MIS 3 European cave bear sites. Only the AMS ${ }^{14} \mathrm{C}$ data of the European MIS 3 cave bears were taken into consideration for this study.

In order to test the validity of the K-index, several correlations between the axes involved in its calculation were carried out. This test was performed on the $2^{\text {nd }}$ metatarsus from the palaeontological excavation.

\section{RESULTS AND DISCUSSION}

\section{$\mathrm{P}^{4} /{ }_{4}$ morphodynamic index}

The dominant p4 morphotypes are $\mathrm{C} 1$ (protoconid, paraconid and metaconid), C2 (C1 + hypoconid), D1 (protoconid, paraconid, metaconid and two small 


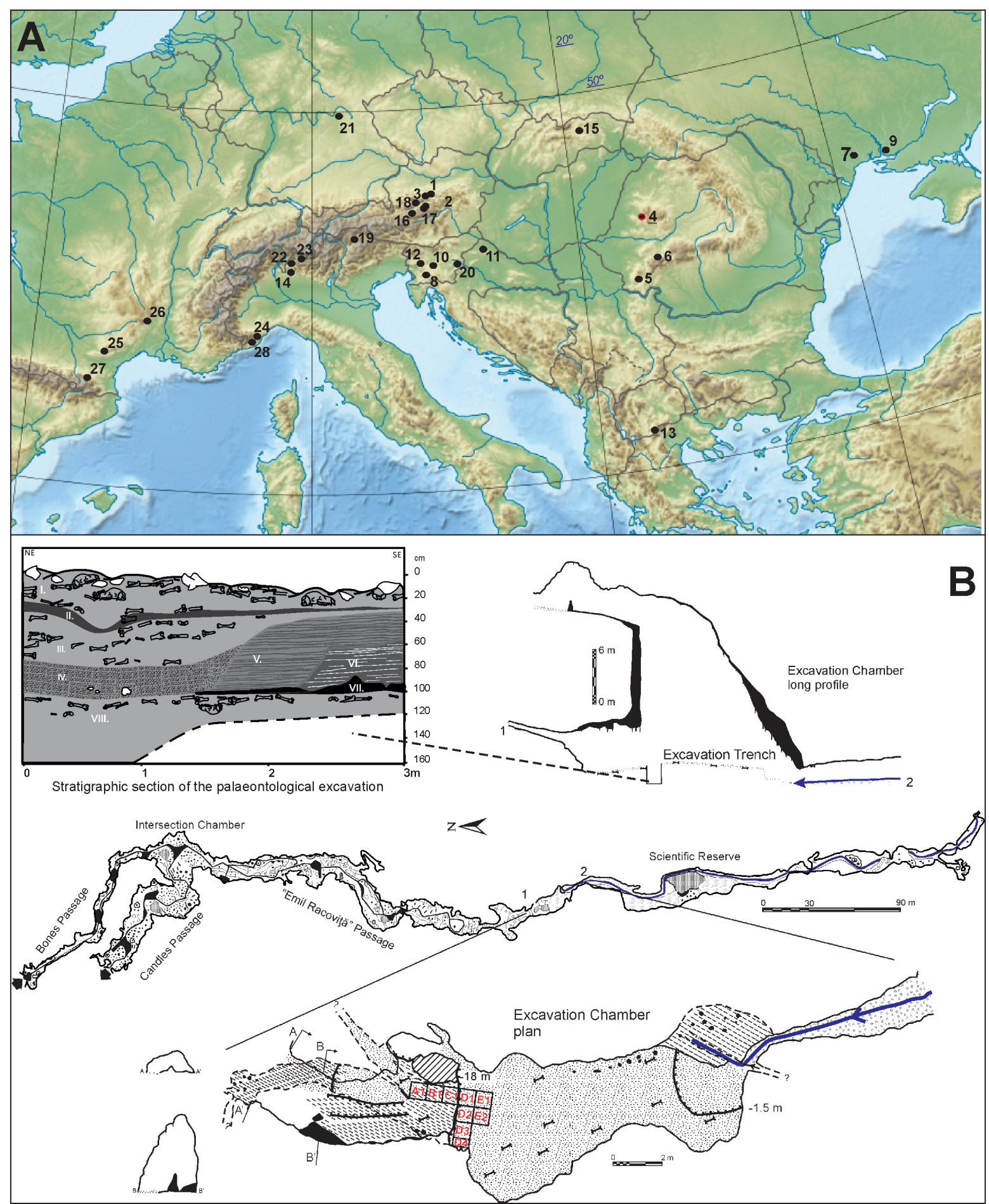

Fig. 1. A) Location of several MIS 3 European cave bear sites; numbers assigned to sites correspond to Table 1; B) Location and topography of Urşilor Cave with position of the palaeontological excavation.

accessory cusps) and D2 (D1 + hypoconid). C1, the most common morphotype of the lower fourth cave bear premolars from this palaeontological excavation, represents $26.21 \%$ of the total number of analyzed specimens. The D1 and D2 morphotypes have the same representation $(14.56 \%)$, while $\mathrm{C} 2$ has a value of $12.62 \%$ (Fig. 3; Table 2).

The dominant P4 morphotypes are D (protocone, metacone, hypocone, metalophe + small accessory cusps) and $\mathrm{E}(\mathrm{D}+\mathrm{a}$ better emphasized metalophulus and hypolophulus). The D morphotype accounts for almost $62 \%$ of the total, while the E morphotype represents $16.50 \%$ (Fig. 3; Table 2).

The p4 index calculated for the cave bears from this palaeontological excavation is 184.95, while the value obtained for P4 is 204.85. After the standardization using the data from Gamssulzen Cave, the standardized $\mathrm{P}^{4} / 4$ index for Urşilor Cave is 65.04 , which places roughly this cave bear population within MIS 3 period and indicate an affiliation to the Ursus ingressus group. Moreover, these results on dental features of the fourth premolar suggest that Urşilor cave bear population is situated at the middle, between the most (e.g., Nixloch, Potočka zijalka) and less developed (e.g., Nerubajskoe) occlusal surfaces of Ursus ingressus populations. Nonetheless, the correlation between the $\mathrm{P}^{4} /{ }_{4}$ index and the radiometric scale $\left(R^{2}=0.25\right)$ of the plotted MIS 3 cave bear sites from Europe indicates a weak interdependence between the two parameters (Fig. 4). 
Table 1. Several MIS 3 European cave bear sites and their biochronological indices. Note: the assigned numbers (\#) to the analyzed sites correspond to Figs. 1,4 , and 5 .

\begin{tabular}{|c|c|c|c|c|c|c|c|c|}
\hline$\#$ & Site & 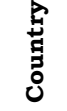 & $\begin{array}{c}\text { Standardized } \\
\mathrm{P}^{4} /{ }_{4} \text { index }\end{array}$ & $\begin{array}{l}\text { Standardized } \\
\text { K-index (2 } \\
\text { metatarsal) }\end{array}$ & $\begin{array}{l}\text { Standardized } \\
\text { Ip (2 } \\
\text { metatarsal })\end{array}$ & $\begin{array}{l}\text { Radiometric } \\
\text { dating } \\
\text { (ky cal BP) }\end{array}$ & Species & Source \\
\hline 1 & Nixloch & $\mathrm{AU}$ & 109.2 & - & - & 28.89 & Ursus ingressus & $\begin{array}{c}\text { Döppes \& Rabeder, 1997; Rabeder, } \\
\text { 1999; Rabeder et al., 2004b; } \\
\text { Pacher \& Stuart, } 2009\end{array}$ \\
\hline 2 & Gamssulzen & $\mathrm{AU}$ & 100 & 100.00 & 100.00 & 40.48 & Ursus ingressus & $\begin{array}{c}\text { Rabeder, 1995; Döppes \& Rabeder, } \\
\text { 1997; Rabeder et al., 2004b; Pacher } \\
\text { \& Stuart, } 2009\end{array}$ \\
\hline 3 & $\begin{array}{l}\text { Herdengel } \\
200-330\end{array}$ & $\mathrm{AU}$ & 58.95 & 95.56 & 96.51 & 40 & Ursus ingressus & $\begin{array}{c}\text { Döppes \& Rabeder, 1997; Rabeder, } \\
\text { 1999; Rabeder et al., 2004b; Pacher } \\
\text { \& Stuart, } 2009\end{array}$ \\
\hline 4 & Urșilor & $\mathrm{RO}$ & 65.04 & 97.87 & 92.11 & 42 & Ursus ingressus? & $\begin{array}{c}\text { Robu et al., 2011; Constantin et al., } \\
\text { 2014; Robu, 2015; 2016a,b. }\end{array}$ \\
\hline 5 & Oase Cave & $\mathrm{RO}$ & 72.5 & - & - & 48 & Ursus ingressus & $\begin{array}{l}\text { Quilès et al., 2006; Richards et al., } \\
2008\end{array}$ \\
\hline 6 & $\begin{array}{l}\text { Cioclovina } \\
\text { Uscata }\end{array}$ & RO & 79.3 & - & - & 40 & Ursus ingressus? & Petrea, 2009 \\
\hline 7 & Ilinka & UK & 50 & 100.18 & 93.87 & 41 & Ursus ingressus & $\begin{array}{l}\text { Rabeder et al., 2008; Nagel et al., } \\
2005\end{array}$ \\
\hline 8 & Križna jama & SLO & 86.19 & 109.59 & 100.72 & 39.62 & Ursus ingressus & $\begin{array}{l}\text { Rabeder \& Nagel, 2001; Pohar et } \\
\text { al., 2002; Rabeder et al., } 2008\end{array}$ \\
\hline 9 & Nerubajskoe & UK & 30 & 86.50 & 95.16 & 52.45 & Ursus ingressus & Nagel et al., 2005 \\
\hline 10 & $\begin{array}{c}\text { Potočka } \\
\text { zijalka }\end{array}$ & SLO & 104 & 103.37 & 102.04 & 30.4 & Ursus ingressus & $\begin{array}{l}\text { Rabeder et al., 2004b; Pacher et al., } \\
\text { 2004; Pacher \& Stuart, } 2009\end{array}$ \\
\hline 11 & Vindija & CR & 63.75 & 110.83 & 100.25 & 39.4 & Ursus ingressus & $\begin{array}{l}\text { Wild et al., 2001; Rabeder et al., } \\
\text { 2004b; Withalm, } 2005\end{array}$ \\
\hline 12 & Divje Babe & SLO & 87 & - & & 47.7 & Ursus ingressus & $\begin{array}{l}\text { Debeljak, 2002; Wild et al., 2001; } \\
\text { Rabeder et al., 2008; Toškan, } 2006\end{array}$ \\
\hline 13 & $\begin{array}{c}\text { Loutra } \\
\text { Arideas }\end{array}$ & MA & 75.66 & 93.78 & 97.01 & 38 & Ursus ingressus & Rabeder et al., 2006 \\
\hline 14 & $\begin{array}{l}\text { Bucco } \\
\text { dell'Orso }\end{array}$ & IT & - & 129.66 & 103.58 & - & Ursus ingressus & $\begin{array}{l}\text { Santi et al., 2011; Santi \& Rossi, } \\
2014\end{array}$ \\
\hline 15 & Medvedia & SL & 79.09 & - & - & 47.1 & Ursus ingressus & Sabol et al., 2008 \\
\hline 16 & Salzofen & $\mathrm{AU}$ & 57.99 & - & - & 49.2 & Ursus eremus & $\begin{array}{c}\text { Döppes \& Rabeder, 1997; Rabeder, } \\
\text { 1999; Rabeder et al., 2008; } \\
\text { Döppes et al., } 2011\end{array}$ \\
\hline 17 & Ramesch 3 & $\mathrm{AU}$ & 52.85 & - & - & 53.2 & Ursus eremus & $\begin{array}{l}\text { Draxler et al., 1986; Döppes \& } \\
\text { Rabeder, 1997; Rabeder, 1999; } \\
\text { Pacher, 2003; Rabeder et al., } \\
\text { 2004b; Döppes et al., } 2011\end{array}$ \\
\hline 18 & $\begin{array}{l}\text { Brettstein- } \\
\text { bären }\end{array}$ & $\mathrm{AU}$ & 53 & 97.87 & 100.66 & 51.3 & $\begin{array}{l}\text { Ursus ladinicus + } \\
\text { Ursus eremus }\end{array}$ & $\begin{array}{l}\text { Döppes \& Rabeder, 1997; Rabeder } \\
\text { et al., 2008; Pacher \& Stuart, } 2009\end{array}$ \\
\hline 19 & Conturines & IT & 63.97 & 88.10 & 97.86 & 44.2 & Ursus ladinicus & $\begin{array}{c}\text { Rabeder, 1991; Rabeder, 1999; } \\
\text { Rabeder et al., 2004b; Hofreiter et } \\
\text { al., } 2004\end{array}$ \\
\hline 20 & $\begin{array}{l}\text { Ajdovska } \\
\text { jama }\end{array}$ & SLO & 46.78 & 100.00 & 94.94 & 50 & Ursus ladinicus & $\begin{array}{c}\text { Rabeder, 2011; Rabeder et al., } \\
\text { 2011; Pacher, 2011; Withalm, } 2011\end{array}$ \\
\hline 21 & $\begin{array}{l}\text { Zooliten- } \\
\text { höhle }\end{array}$ & GE & 42 & 100.89 & 92.93 & 34.7 & Ursus s. spelaeus & $\begin{array}{c}\text { Rabeder et al., 2004b; Hofreiter et } \\
\text { al., } 2004\end{array}$ \\
\hline 22 & $\begin{array}{l}\text { Fontana } \\
\text { Marella }\end{array}$ & IT & 57.8 & - & - & 26 & Ursus ingressus? & $\begin{array}{c}\text { Toskan \& Bona, 2012; Santi \& } \\
\text { Rossi, } 2014\end{array}$ \\
\hline 23 & $\begin{array}{l}\text { Caverna } \\
\text { Generosa }\end{array}$ & IT & 56.82 & - & - & 47.14 & Ursus ingressus? & $\begin{array}{l}\text { Bona, 2004; Pacher \& Stuart, } \\
\text { 2009; Santi \& Rossi, } 2014\end{array}$ \\
\hline 24 & Basura & IT & 95.1 & - & - & 27.5 & $\begin{array}{l}\text { Ursus s. } \\
\text { spelaeus? }\end{array}$ & Quilès et al., 2006; Petrea, 2009 \\
\hline 25 & Tournal & FR & 73.4 & - & - & 35 & $\begin{array}{l}\text { Ursus s. } \\
\text { spelaeus? }\end{array}$ & Santi \& Rossi, 2014 \\
\hline 26 & Hortus & FR & 80.9 & - & - & 40 & $\begin{array}{l}\text { Ursus s. } \\
\text { spelaeus? }\end{array}$ & Petrea, 2009; Santi \& Rossi, 2014 \\
\hline 27 & $\begin{array}{l}\text { Grotte } \\
\text { Blanche }\end{array}$ & FR & 79.8 & - & - & 40 & $\begin{array}{l}\text { Ursus s. } \\
\text { spelaeus? }\end{array}$ & Petrea, 2009 \\
\hline 28 & Badalucco & IT & 72.4 & - & - & 50 & $\begin{array}{l}\text { Ursus s. } \\
\text { spelaeus? }\end{array}$ & Petrea, 2009 \\
\hline
\end{tabular}




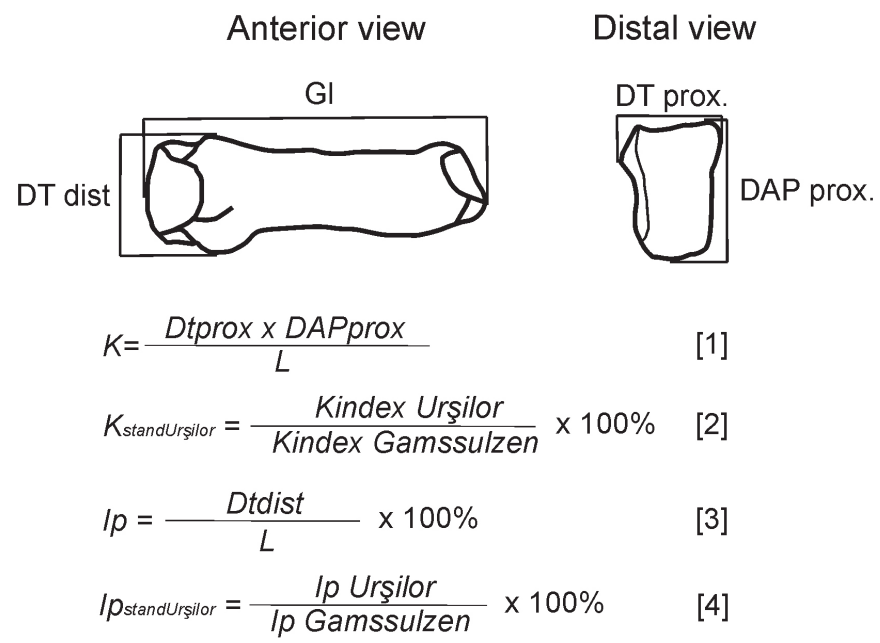

Fig. 2. Osteometric measurements and the equations used for the calculation of K-index and Index of Plumpness.

Table 2. The cave bear upper (P4) and lower (p4) morphotypes from the palaeontological excavation.

\begin{tabular}{|c|c|c|c|c|}
\hline \multicolumn{5}{|l|}{ Upper P4 } \\
\hline Morphotype & Amount & Factor & Product & Frequency $(\%)$ \\
\hline B & 3 & 1 & 3 & 2.91 \\
\hline $\mathrm{C}$ & 3 & 2 & 6 & 2.91 \\
\hline $\mathrm{A} / \mathrm{D}$ & 13 & 1 & 13 & 12.62 \\
\hline $\mathrm{D}$ & 64 & 2 & 128 & 62.14 \\
\hline $\mathrm{E}$ & 17 & 3 & 51 & 16.50 \\
\hline $\mathrm{D} / \mathrm{F}$ & 1 & 3 & 2 & 0.97 \\
\hline $\mathrm{F}$ & 2 & 4 & 8 & 1.94 \\
\hline TOTAL & 103 & & 211 & 100 \\
\hline \multicolumn{5}{|l|}{ Lower p4 } \\
\hline Morphotype & Amount & Factor & Product & Frequency $(\%)$ \\
\hline B1 & 6 & 0.5 & 3 & 5.82 \\
\hline B2 & 2 & 2 & 4 & 1.94 \\
\hline $\mathrm{C} 1$ & 27 & 1 & 27 & 26.21 \\
\hline $\mathrm{C} 2$ & 13 & 2 & 26 & 12.63 \\
\hline C3 & 8 & 3 & 24 & 7.76 \\
\hline D1 & 15 & 1.5 & 22.5 & 14.57 \\
\hline D2 & 15 & 2.5 & 37.5 & 14.57 \\
\hline D3 & 7 & 3.5 & 24.5 & 6.79 \\
\hline E1 & 9 & 2 & 18 & 8.73 \\
\hline E3 & 1 & 4 & 4 & 0.98 \\
\hline TOTAL & 103 & & 190.5 & 100 \\
\hline
\end{tabular}
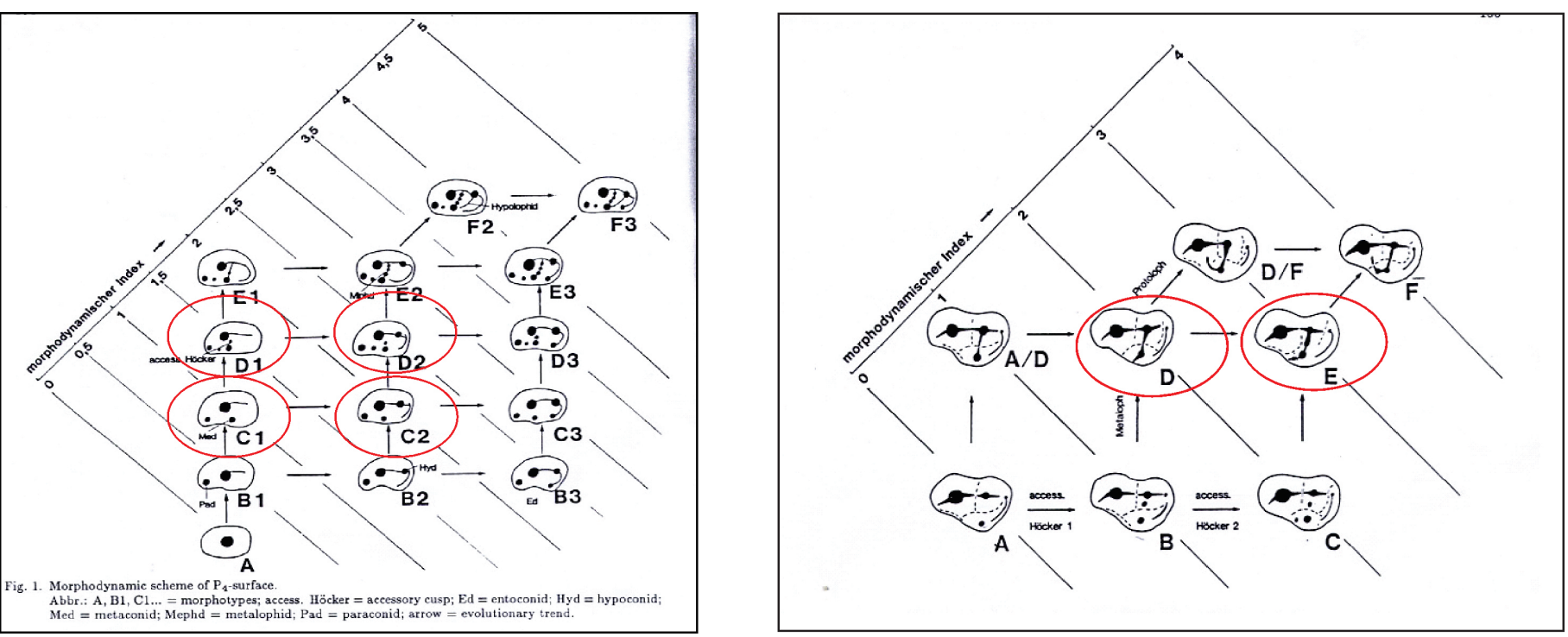

Fig. 3. Main $\mathrm{P}_{4} / 4$ morphotypes from Urşilor Cave. 


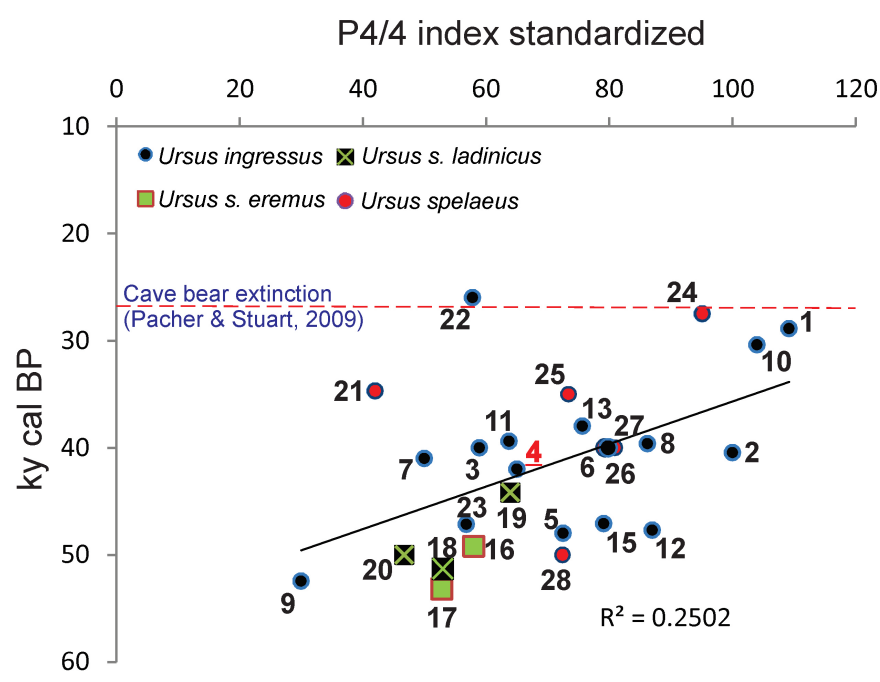

Fig. 4. Radiometric ages vs. $\mathrm{P}^{4 / 4}$ standardized index for several European cave bear sites. Note: numbers assigned to sites correspond to Table 1.

For the pooled cave bear fourth premolars from Urşilor, a biochronological estimate of 60-40 ky BP was obtained based on the assumed error of the morphodynamic method and taking into account the cave bear extinction date, situated around $27.8 \mathrm{cal} \mathrm{ky}$ BP (Pacher \& Stuart, 2009).

At the European continental scale, spanning a time period of almost 140 ky BP (Rabeder \& Tsoukala, 1990; Quilès et al., 2006), the dental morphotype indices are well correlated with the radiometric scale, and therefore, the $\mathrm{P}^{4} /{ }_{4}$ morphodynamic index has proved to be a reliable biochronological tool (e.g., Rabeder, 1999; Quilès, 2004). Nevertheless, in the case of the plotted European MIS 3 cave bear populations, the relevance of the calculated index looses its validity: the correlation between the $\mathrm{P}^{4} /{ }_{4}$ index and the radiometric scale of is weak $\left(R^{2}=0.25\right)$. This could be explained by 1) the amount of new radiocarbon data obtained through AMS using ultrafiltration, which have given significantly older dates on the same fossil material (Higham et al., 2006a, b; Jacobi et al., 2006; Mellars, 2006; Pacher \& Stuart, 2009) and 2) the contradiction between the obtained $\mathrm{P}_{4}^{4} /{ }_{4}$ index and the radiocarbon data [e.g., the values of the morphodynamic index obtained for Oase Cave (72.5; see Table 1) indicated a more advanced evolutionary stage for the cave bears than at Urşilor Cave, while the obtained radiometric ages clearly show that the latter site was younger than Oase Cave].

Therefore, one of the main limitations of the $\mathrm{P}^{4} / 4$ morphodynamic method (when attempting to estimate the age of a MIS 3 cave bear bone population), is that the long-term adaptive features in addition to the local environmental conditions affect the fourth premolar's "plasticity". In other words, although the radiometric results may point to a younger cave bear population at one site than at another, the former may retain less complex features in the dental configuration than the latter. In this situation, the main constraint cannot be the general trend of the evolution, but the local environmental factors or other constraints (e.g., the geographic and reproductive isolation, the variability of $\mathrm{P}^{4} / 4$ 's occlusal surface in a given place and time, dietary habits, etc.) that could have shaped the $\mathrm{P}^{4} / 4$, morphology differently for various populations. The second main limitation is that within MIS 3 , the $\mathrm{P}^{4} / 4$ morphodynamic index has a very low resolution (the errors of the method are far too large for this period). As such, it is hard to assess the evolutionary stage of a cave bear population, especially when $\mathrm{P}^{4} / 4$ ' "molarisation" was not necessarily an evolutionary trend as they approached extiction but seems rather related to the variability of this species during MIS 3. Consequently, based on our new biochronological results obtained from Urşilor Cave we consider that the use of the $\mathrm{P}^{4} / 4$ morphodynamic estimation is a less reliable tool when trying to assess and to compare the $\mathrm{P}^{4} /{ }_{4}$ dental features between cave bear populations from similar time periods (e.g., 45-40 ky BP).

Nonetheless, the method can be applied with caution when no radiometric ages are available for the fossil remains and when the evolutionary stage of the cave bear population has to be broadly assessed. Moreover, based on the biochronological estimates obtained from the quantification of the $\mathrm{P}^{4} /{ }_{4}$ occlusal surface of cave bears from the European sites it appears that the $\mathrm{P}^{4} / 4$ index may provide reliable information when conducting studies on a regional scale and at larger time.

\section{K-index and Index of Plumpness}

The $\mathrm{K}$-index value obtained for the $2^{\text {nd }}$ metatarsal of the cave bears from the palaeontological excavation is 5.51 (Table 3). After standardization using the data from Gamssulzen Cave, a K-index value of 97.86 was recorded for Urşilor Cave.

Figure 5A shows the distribution of the best studied European cave bear sites (e.g., Rabeder, 1999, 2004; Gužvica \& Radanović-Gužvica, 2000; Withalm, 2004, 2011) taking into consideration two variables: the $\mathrm{K}$-index and the radiocarbon data. As the occlusal surface of the fourth premolar indicates, the values obtained for the cave bears from the palaeontological excavation point to a cave bear population situated at an earlier evolutionary stage when compared to the other western and central European Ursus ingressus cave bear populations. However, the result of the correlation $\left(R^{2}=0.22\right)$, between the radiometric scale and the K-index from the analyzed sites, suggests that $\mathrm{K}$-index should be regarded with caution as a biochronological proxy.

The Index of Plumpness calculated for the $2^{\text {nd }}$ metatarsal of the cave bear population from Urşilor Cave is 29.31 (Table 3). Figure 5B shows the available standardized indices of Plumpness plotted against the radiometric scale from the European cave bear sites. Among the analyzed cave bear sites, Urşilor population has the lowest value of the Index of Plumpness, although the obtained radiometric data place this population later than other sites with higher values of robusticity. The correlation between radiocarbon data and Ip is weak $\left(R^{2}=0.03\right)$ and apparently, as in the case of the K-index, the assumed biochronological relevance of this index is questionable.

It is known that during MIS 3 different cave bear species/subspecies coexisted (even in the same site; e.g., Gamssulzen and Ramesch caves; Bocherens et al., 2011), sometimes showing different body 
A

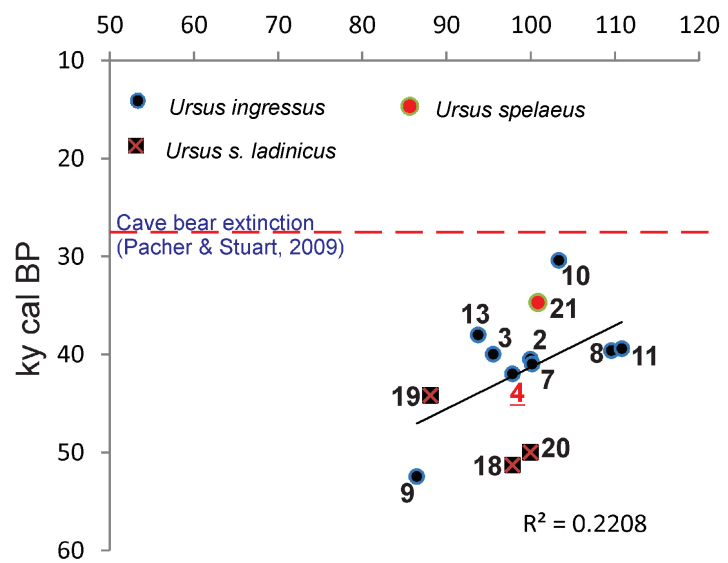

B

Index of Plumpness standardized

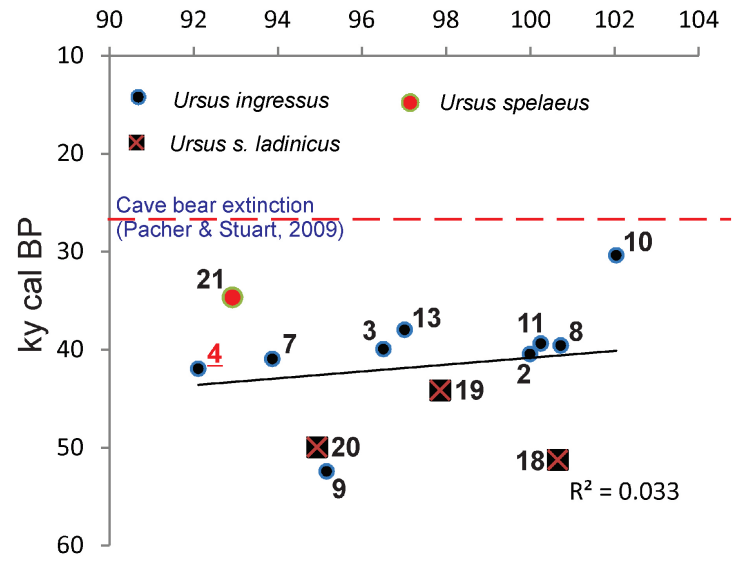

Fig. 5. A) Radiometric ages vs. standardized K-index index for several European cave bear sites; B) Radiometric ages vs. standardized Index of Plumpness for several European cave bear sites. Note: numbers assigned to sites correspond to Table 1

Table 3. Measurements of the cave bear metapodials from Urşilor Cave (according to Tsoukala \& Grandal D'Anglade, 2002). Note: $M c=$ metacarpals; $M t=$ metatarsals; $L=$ greatest length; $D T$ prox. $=$ the proximal breadth; DAP prox. $=$ the proximal height; DT dia.min. = minimum breadth of diaphysis; DAP dia. = diaphysis' height; DT dist. = the distal breadth; DAP dist. $=$ the distal height; DT art.dist. $=$ the distal articulation breadth .

\begin{tabular}{|c|c|c|c|c|c|c|c|c|c|c|}
\hline Elements & Mc 1 & Mc 2 & Mc 3 & Mc 4 & Mc 5 & Mt 1 & Mt 2 & Mt 3 & Mt 4 & Mt 5 \\
\hline $\mathbf{L}$ & 63.51 & 75.87 & 80.94 & 83.22 & 83.16 & 55.52 & 69.23 & 78.36 & 85.77 & 90.05 \\
\hline DT prox. & 23.53 & 18.51 & 20.07 & 21.74 & 27.54 & 21.92 & 15.87 & 20.05 & 20.01 & 28.14 \\
\hline DAP prox. & 20.73 & 25.3 & 29.01 & 30.49 & 30.54 & 23.48 & 24.03 & 29.12 & 29.57 & 29.85 \\
\hline DT dia.min. & 13 & 17.01 & 16.5 & 18.25 & 18.3 & 11.1 & 13.56 & 15.09 & 15.27 & 13.83 \\
\hline DAP dia. & 11.2 & 13.12 & 13.4 & 15.46 & 14.7 & 12.2 & 10.35 & 11.48 & 13.41 & 14.87 \\
\hline DT dist. & 18.26 & 24.04 & 24.35 & 26.04 & 27.01 & 17.14 & 20.3 & 21.23 & 22.55 & 24.4 \\
\hline DAP dist. & 17.3 & 19.63 & 20.49 & 21.17 & 20.16 & 15.66 & 16.24 & 16.87 & 17.7 & 17.74 \\
\hline DT art.dist. & 12.27 & 16.36 & 15.91 & 15.91 & 16.72 & 10.72 & 12.71 & 12.78 & 14.95 & 14.82 \\
\hline Ip & 28.75 & 31.68 & 30.08 & 31.29 & 32.47 & 30.87 & 29.31 & 27.09 & 26.28 & 27.1 \\
\hline $\mathbf{K}$ & 7.68 & 6.17 & 7.19 & 7.37 & 10.11 & 9.27 & 5.51 & 7.45 & 6.9 & 9.32 \\
\hline
\end{tabular}

sizes and biometric peculiarities. Therefore, several correlations were tested for a better understanding of the K-index and for its biochronological relevance. The working assumption was that if there is a strong interdependence among all the parameters the greatest length, the DAP prox (antero-posterior diameter of the proximal epiphysis) and the DT prox (transverse diameter of the proximal epiphysis) - then the equation proposed by Gužvica \& RadanovićGužvica (2000) has no biochronological meaning (strong correlations among all the axes, indicate that the largest bears (as size of the skeleton) will produce only high values for the K-index, but not a palaeoevolutionary proxy). The results indicated that:

(i) the correlation between the DAP prox and the K-index (Fig. 6A) of the $2^{\text {nd }}$ metatarsal of the cave bears from the palaeontological excavation at Urşilor Cave is significant $\left(R^{2}=0.70\right)$;

(ii) the correlation between the K-index and the greatest length (or maximum length) of the second metatarsal (Fig. 6B) is non-significant $\left(R^{2}=0.37\right)$;

(iii) figure $7 \mathrm{~A}$ shows a strong correlation $\left(R^{2}=0.90\right)$ between the K-index and the (DT prox);

(iv) the correlation between the DAP prox and the DT prox (Fig. 7B) is moderate $\left(R^{2}=0.59\right)$ and indicates that the axes are not interdependent;

(v) figure 8A shows a significant correlation between the maximum length and the antero-posterior diameter $\left(R^{2}=0.76\right)$ of the cave bear $2^{\text {nd }}$ metatarsal; (vi) the maximum length and the transverse diameter of the proximal epiphysis (Fig. 8B) shows no interdependence between the axes $\left(R^{2}=0.46\right)$.

$\mathrm{K}$-index appears to reflect the robusticity of the proximal end of the metatarsals. As Withalm (2004) mentioned, K-index values obtained for cave bears increased as they approached extinction [i.e., older bears (from deeper stratigraphic layers) show lower values than those from younger strata]. These correlations have shown that the maximum length of the $2^{\text {nd }}$ metatarsal exhibits a pattern similar to that of the antero-posterior diameter, while the transverse diameter does not show a clear interdependence with either the maximum length or DAP. For the $2^{\text {nd }}$ metatarsal of the cave bears from the palaeontological excavation, DAP and maximum length seem to be interrelated, while DT behaves as an independent parameter.

Nonetheless, for a better assessment of the age estimation of a cave bear population, the obtained $\mathrm{K}$-index has to be correlated with the $\mathrm{P}^{4} / 4$ index and with the Index of Plumpness. Thus, if the $\mathrm{P}^{4} / 4$ morphodynamic index, $\mathrm{K}$-index and Index of Plumpness are correlated with the radiometric scale (Withalm, 2004), the obtained results might be of biochronological relevance. However, the main concern, as in the case of the $\mathrm{P}^{4} / 4$ index (for both K-index and the Ip) is the resolution of the methods - errors far too large for a 

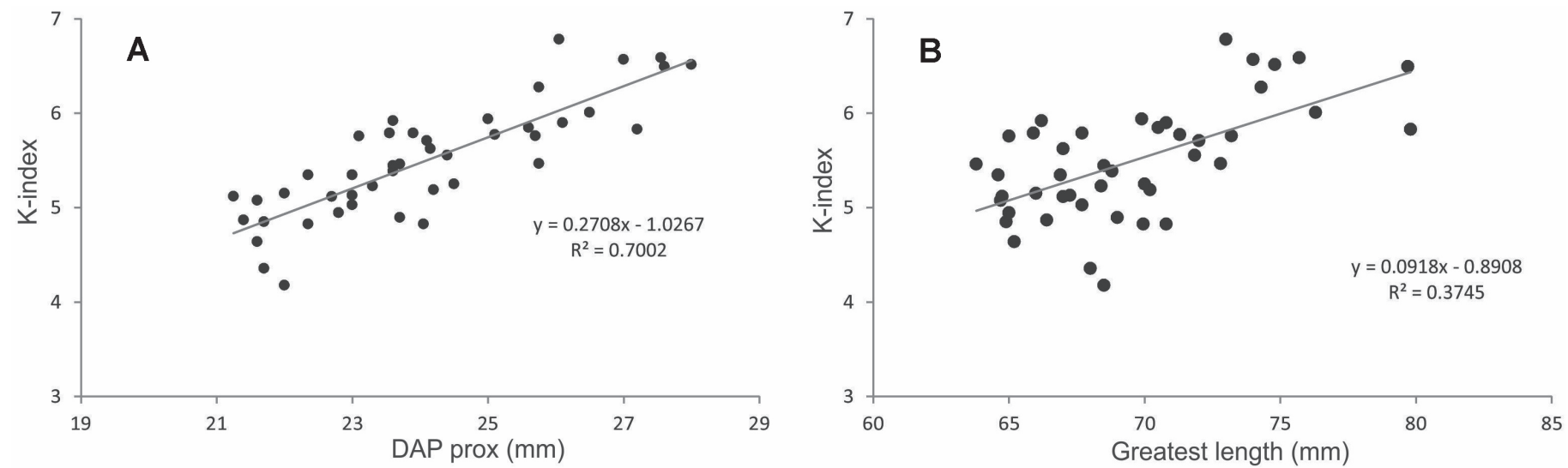

Fig. 6. A) K-index vs. DAP prox for the $2^{\text {nd }}$ cave bears metatarsal; B) K-index vs. Gl for the $2^{\text {nd }}$ metatarsal of the cave bears from the palaeontological excavation from Urşilor Cave.
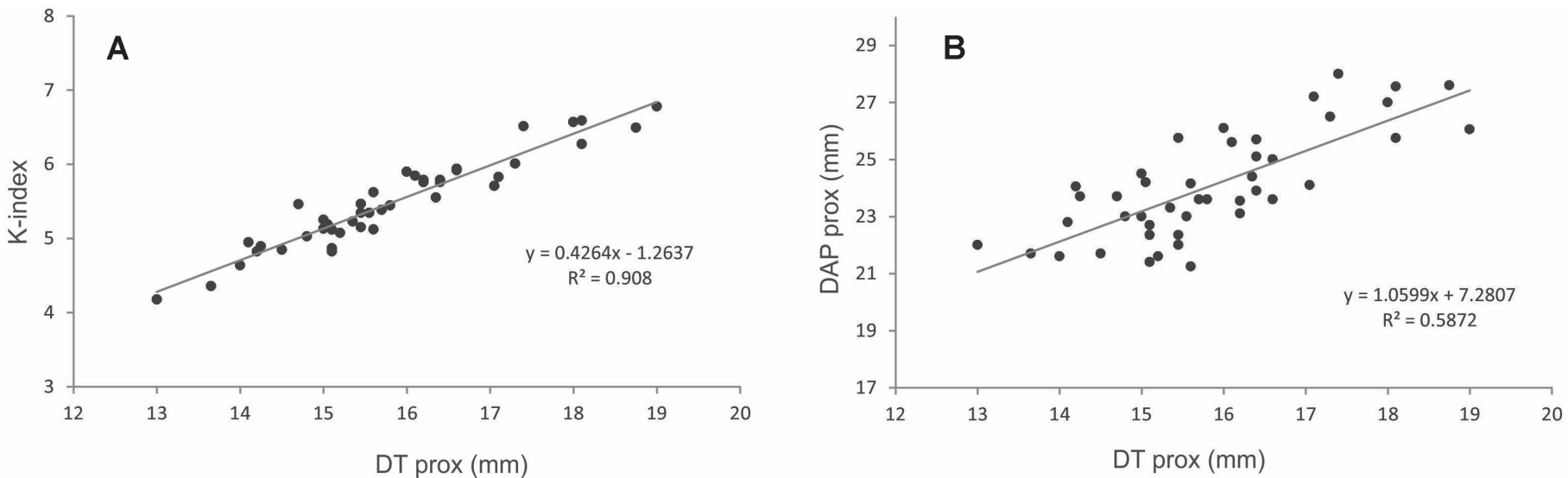

Fig. 7. A) K-index vs. DT prox for the $2^{\text {nd }}$ metatarsal; B) DAP vs. DT for the $2^{\text {nd }}$ metatarsal of the cave bears from Urşilor Cave.
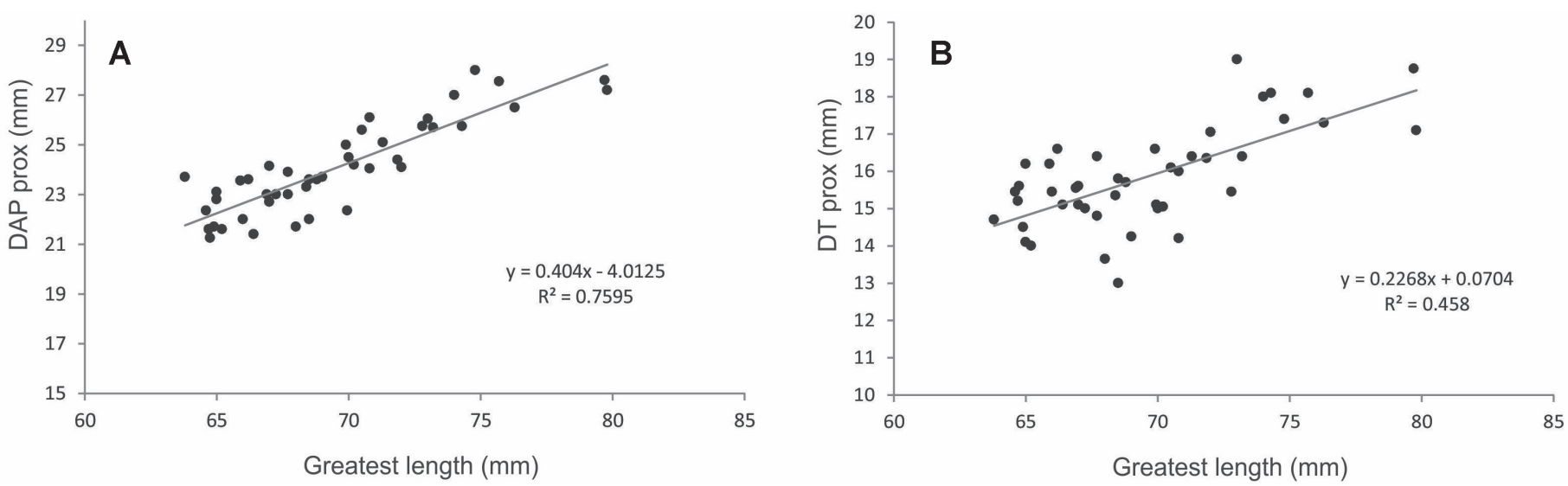

Fig. 8. A) DAP prox vs. greatest length for the 2 nd metatarsal; B) DT prox vs. greatest length for the $2^{\text {nd }}$ metatarsal of the cave bears from Urşilor Cave.

precise evaluation of the age of the MIS 3 cave bear populations.

\section{CONCLUSIONS}

Based on the morphodynamic dataset $\left(\mathrm{P}^{4} / 4\right)$ and indices for $2^{\text {nd }}$ metatarsus ( $\mathrm{K}$ and Ip indices), Urşilor Cave bear population is allocated to an earlier evolutionary stage than previously assumed by Robu et al. (2011). Most likely this cave bear population belongs to a more ancient branch - with less evolved dental and metapodial features - of Ursus ingressus population (eastern clade) when compared with similar MIS 3 populations from the alpine region (western clade). The earlier evolutionary stage might indicate an older period, a fact also supported by the radiometric data.
All three methods, $\mathrm{P}^{4} / 4$ morphodynamic index, $\mathrm{K}$-index, and Index of Plumpness, often used for the cave bear evolutionary stage assessment, are biochronologically relevant when corroborated and applied at a regional scale and to large time intervals. For the MIS 3 cave bear populations, the use of these three indices for biochronological purposes, without proper radiometric dating, may be unreliable.

Over the last 30 years, the radiometric ages were obtained using different procedures (e.g., conventional ${ }^{14} \mathrm{C}$, AMS ${ }^{14} \mathrm{C}$ with ultrafiltration), thus a full reassessment of both the biochronological $\left(\mathrm{P}^{4} / 4, \mathrm{~K}\right.$, and $\mathrm{Ip}$ indices) and the radiometric data - for the most relevant cave bear sites - is needed. Until then, all correlations of the biochronological indices vs. the radiometric scale should be interpreted with caution. 


\section{ACKNOWLEDGEMENTS}

This study was supported by the KARSTHIVES Project - "Climate archives in karst", funded by CNCSUEFISCDI Grant PCCE_ID 31/2010. The author is indebted to Dr. Silviu Constantin and to Dr. OanaTeodora Moldovan for their scientific support, to Dr. Chris Robinson and Dr. Sabrina Curran for advices and English revision. Further, I am grateful to my colleagues from "Emil Racoviță" Institute of Speleology - Dr. Alexandru Petculescu, Ionuț-Cornel Mirea, Marius Kenesz, Dr. Augustin Nae, Marius Vlaicu, Dr. Cristian-Mihai Munteanu, Dr. Ioana-Nicoleta Meleg and Toma Valerică - for their field assistance and scientific support and to the volunteers from the Faculty of Geography from Bucharest University - Roxana Constantin, Alina Diaconu, Beatrice Barbu, Irina Năstase, Alexandra Hristea, Cristian Țepurică and Teodora Badea - for helping with bone preservation, labeling and for building the database.

Moreover, the author is indebted to Dr. Gerhard Withalm for providing data from the Alpine cave bear sites, and to the three anonymous reviewers who significantly improved the quality of this manuscript.

\section{REFERENCES}

Baca M., Stankovic A., Stefaniak K., Marciszak A., Hofreiter M., Nadachowski A., Wegleński P. \& Mackiewicz P., 2012 - Genetic analysis of cave bear specimens from Niedźwiedzia Cave, Sudetes, Poland. Palaeontologia Electronica, 15 (2): 16 p.

Bocherens H., Stiller M., Hobsond K.A., Pacher M., Rabeder G., Burns J.A., Tütken T. \& Hofreiter M., 2011 - Niche partitioning between two sympatric genetically distinct cave bears (Ursus spelaeus and Ursus ingressus) and brown bear (Ursus arctos) from Austria: Isotopice evidence from fossil bones. Quaternary International, 245: 238-248.

http://dx.doi.org/10.1016/j.quaint.2010.12.020

Bona F., 2004 - Preliminary analysis on Ursus spelaeus Rosenmüller \& Heinroth, 1794 populations from "Caverna Generosa" (Lombardy - Italy). Cahiers scientifiques, 2: 87-98.

Constantin S., Robu M., Munteanu C.M., Petculescu A., Vlaicu M., Mirea I., Kenesz M., Drăgussin V., Hoffman D., Anechitei V., Timar-Gabor A., Roban R. \& Panaiotu C.G., 2014 - Reconstructing the evolution of cave systems as a key to understanding the taphonomy of fossil accumulations: The case of Ursilor Cave (Western Carpathians, Romania). Quaternary International, 339-340: 25-40.

http://dx.doi.org/10.1016/i.quaint.2013.10.012

Debeljak I., 2002 - Fossil population structure of the cave bear from Divje Babe I site, Slovenia: Preliminary results. Abhandlung zur Karst- und Höhlenkunde, 34: 41-48.

Döppes D. \& Rabeder G., 1997 - Pliozäne und pleistozäne Faunen Österreichs. Ein Katalog der wichtigsten Fossilfundstellen und ihrer Faunen. Mitteilungen der Kommission für Quartärforschung der Österreichischen Akademie der Wissenschaften, 10, $267 \mathrm{p}$.

Döppes D., Rabeder G. \& Stiller M., 2011 - Was the Middle Würmian in the High Alps warmer than today? Quaternary International, 245: 193-200.

http://dx.doi.org/10.1016/j.quaint.2011.07.029
Draxler I., Hille P., Mais K., Steffan I. \& Wild E., 1986 - Paläontologische Befunde, absolute Datierungen und paläoklimatologische Konsequenzen der Resultate aus der Ramesch-Knochenhöhle. In: Hille P. \& Rabeder G. (Eds.), Die Ramesch-Knochenhöhle im Toten Gebirge. Mitteilungen der Kommission für Quartärforschung Österreichische Akademie der Wissenschaften, 6: 6-66.

Gužvica R., Radanovicić-Gužvica B., 2000 - Comparative evolutional analysis of cave bear metapodial bones from North-Western Croatia. Geologicki Zbornik, 15: 17-19.

Higham T.G., Jacobi R.M. \& Ramsey C.B., 2006a - AMS radiocarbon dating of ancient bone using ultrafiltration. Radiocarbon, 48: 179-195.

Higham T., Ramsey C.B., Karavanic I., Smith F.H. $\&$ Trinkaus E. 2006b - Revised direct radiocarbon dating of the Vindija G1 Upper Paleolithic Neandertals. Proceedings of the National Academy of Sciences of the United States of America, 103: 553-557.

http://dx.doi.org/10.1073/pnas.0510005103

Hofreiter M., Rabeder G., Jaenicke-Després V., Withalm G., Nagel D., Paunivic M., Jambrěsic G. \& Pääbo S., 2004 - Evidence for reproductive isolation between cave bear Populations. Current Biology 14: 40-43.

http://dx.doi.org/10.1016/j.cub.2003.12.035

Jacobi R.M., Higham T.G. \& Bronk Ramsey C., 2006 - AMS radiocarbon dating of Middle and Upper Paleolithic bone in the British Isles: Improved reliability using ultrafiltration. Journal of Quaternary Science, 21: 557-574. http://dx.doi.org/10.1002/jqs.1037

Jurcsák T., Plopiş R., Ignat D., Şerban M. \& Popa E., 1981 - Date privind fauna fosilă a Peşterii Urşilor (M. Bihor). Nymphaea, 8-9: 161-257.

Knapp M., Rohland N., Weinstock J., Baryshnikov G., Sher A., Nagel D., Rabeder G., Pinhasi R., Schmidt H.A. \& Hofreiter M., 2009 - First DNA sequences from Asian cave bear reveal deep divergences and complex phylogeographic patterns. Molecular Ecology, 18: 1225-1238.

http://dx.doi.org/10.1111/j.1365-294X.2009.04088.x

Mellars P. 2006 - A new radiocarbon revolution and the dispersal of modern humans in Eurasia. Nature, 439: 931-935. http://dx.doi.org/10.1038/nature04521

Nagel D., Pronin K., Rabeder G., Hofreiter M., Huijer W., Kavcik N., Urbanek C., Withalm G. \& Orlov N., 2005 - Nerubajskoe, a new cave bear site in the Old Nordmann Territory. Mitteilungen der Kommission für Quartärforschung Österreichische Akademie der Wissenschaften, 14: 123-134.

Pacher M., 2003 - Upper Pleistocene cave assemblages at alpine sites in Austria and adjacent regions. Preistoria Alpina, 39: 115-118.

Pacher M., 2011 - Late Pleistocene large mammal remains from Ajdovska jama near Krško, Slovenia. In: Pacher M., Pohar V. \& Rabeder G. (Eds.), Ajdouska jama Palaeontology, zoology and archaeology of Ajdouska jama near Krško. Mitteilungen der Kommission für Quartärforschung der Österreichischen Akademie der Wissenschaften, 20: 17-25.

Pacher M. \& Stuart A.J., 2009 - Extinction, chronology and palaeobiology of the cave bear Ursus spelaeus. Boreas, 38 (2): 189-206.

http://dx.doi.org/10.1111/j.1502-3885.2008.00071.x

Pacher M., Pohar V. \& Rabeder G. (Eds.), 2004 - Potočka zijalka. Palaeontological and archeological results of the campaigns 1997-2000. Mitteilungen der Kommission für Quartärforschung Österreichische Akademie der Wissenschaften, 13: 1-245. 
Petrea C., 2009 - Paleontological and taphonomic characters of Ursus spelaeus fossils from Cioclovina Cave. In: Petculescu A. \& Murariu D. (Eds.), The first ecological reconstruction of underground environment from Romania, Cioclovina Uscată Cave. Editura Universitară, Bucharest, p. 67-86.

Pettitt P. \& White M., 2012 - The British Palaeolithic: Human societies at the edge of the Pleistocene world. Abingdon, UK: Routledge, 592 p.

Pohar V., Rabeder G., Kralj P. \& Misic M., 2002 - Cave sediments and fossil mammal remains in Križna jama, Southern Slovenia. Abhandlung zur Karst- und Höhlenkunde, 34: 49-51.

Quilès J., 2004 - Analyse morphodynamique de l'ours des caverns (Carnivora, Ursidae) de cinq sites du pourtour méditerranéen. In: M. Philippe, A. Argant \& Argant J. (Eds.), $9^{\text {th }}$ International Cave Bear Symposium. Cahiers Scientifiques, Hors Série, 2: 149-161.

Quilès J., Petrea C., Moldovan O., Zilhao J., Rodrigo R., Rougier H., Constantin S., Milota S.., Gherase M., Sarcină L. \& Trinkhaus E., 2006 - Cave bears (Ursus spelaeus) from Peştera cu Oase (Banat, Romania): Paleobiology and taphonomy. Comptes Rendus Palevol, 5: 927-934. http://dx.doi.org/10.1016/j.crpv.2006.09.005

Rabeder G., 1989 - Modus und Geschwindikeit der Hohlenbaren-Evolution. Schriften des Vereines zur Verbreitung naturwissenschaftlicher Kenntnisse, 127: 105-126.

Rabeder G., 1991 - Die Höhlenbären von Conturines. Entdeckung und Erforschung einer Dolomiten-Höhle in $2800 \mathrm{~m}$ Höhe. Athesia, Bozen, 125 p.

Rabeder G., 1995 - Die Gamssulzenhöhle im Toten Gebirge. Mitteilungen der Kommission für Quartärforschung der Österreichischen Akademie der Wissenschaften, 9: 1-133.

Rabeder G., 1999 - Die evolution des höhlenbärengebisses. Mitteilungen der Kommission für Quartärforschung der Österreichischen Akademie der Wissenschaften, 11: 1-90.

Rabeder G., 2004 - Evolutionary level of the cave bear teeth from Potočka zijalka (Slovenia). In: Pacher M., Pohar V. \& Rabeder G. (Eds.), Potočka zijalka - palaeontological and achaeological results of the excavation campaigns 1997-2000. Mitteilungen der Kommission für Quartärforschung der Österreichischen Akademie der Wissenschaften, 13: 197-200.

Rabeder G., 2011 - Evolutionary level and metric data of bear teeth from Adjouska jama near Krsko (Slovenia). Mitteilungen der Kommission für Quartärforschung der Österreichischen Akademie der Wissenschaften, 20: 31-42.

Rabeder G. \& Tsoukala E., 1990 - Morphodynamic analysis on some cave-bear teeth from Petralona cave (Chalkidiki, Greece). Beitrage der Paläontolgie Österreich, 16: 103-109.

Rabeder G. \& Nagel D., 2001 - Phylogenetic problems of the alpine cave bears. Cuadernos do Laboratorio Xeolóxico de Laxe, 26: 359-364.

Rabeder G., Hofreiter M., Nagel D., Withalm G. \& 2004a - New taxa of alpine cave bears (Ursidae, Carnivora). Cahiers scientifiques, Départament Rhône - Muséum. Hors série, 2: 49-67.

Rabeder G., Hofreiter M. \& Withalm G., 2004b - The Systematic Position of the Cave Bear from Potočka zijalka (Slovenia). In: Pacher M., Pohar V. \& Rabeder G. (Eds.), Potočka zijalka - palaeontological and achaeological results of the excavation campaigns 1997-2000. Mittelungen der Kommission für Quartärforschung der Österreichischen Akademie der Wissenschaften, 13: $197-200$.
Rabeder G., Tsoukala E. \& Kavcik N., 2006-Chronological and systematic position of cave bears from Loutrá Aridéas (Pella, Macedonia, Greece). Scientific Annals, School of Geology Aristotle University of Thessaloniki (AUTH), 98: 69-73.

Rabeder G., Hofreiter M. \& Stiller M., 2011 Chronological and systematic position of cave bear fauna from Adjouska jama near Křsko (Slovenia). Mitteilungen der Kommission für Quartärforschung der Österreichischen Akademie der Wissenschaften, 20: $79-85$.

Rabeder G., Debeljak I., Hofreiter M. \& Withalm, G., 2008 - Morphological responses of cave bears (Ursus spelaeus group) to high-alpine habitats. Die Höhle, 1-4: 59-72.

Richards M. P., Pacher M., Stiller M., Quiles J., Hofreiter M., Constantin S., Zilhao J. \& Trinkaus E., 2008 - Isotopic evidence for omnivory among European cave bears: Late Pleistocene Ursus spelaeus from the Peştera cu Oase, Romania. Proceedings of the National Academy of Sciences U.S.A., 105 (2): 600-604. http://dx.doi.org/10.1073/pnas.0711063105

Robu M., 2015 - The palaeontology of the cave bear bone assemblage from Urşilor Cave of Chişcău - Osteometry, palaeoichnology, taphonomy, and stable isotopes. Editura Universitară, Bucharest, 248 p.

Robu M, 2016a - The assessment of the internal architecture of an MIS 3 cave bear bone assemblage. Case study: Urşilor Cave, Western Carpathians, Romania. Palaeogeography, Palaeoclimatology, Palaeoecology, 444: 115-123. http://dx.doi.org/10.1016/i.palaeo.2015.12.012

Robu M., 2016b - Fossil population structure and mortality analysis of the cave bears from Urşilor Cave, north-western Romania. Acta Palaeontologica Polonica (in press). http://dx.doi.org/10.4202/app.00201.2015

Robu M., Petculescu A., Panaiotu C., Doeppes D., Vlaicu M., Dragussin V., Kenesz M. \& Constantin, S., 2011 New insights on the cave bear population from the Urşilor Cave, Romania. Quaternaire, Hors-série, 4: 107-116.

Santi G. \& Rossi M., 2014 - Metapodial bones of Ursus gr. spelaeus from selected caves of the North Italy. A biometrical study and evolutionary trend. Annales de Paléontologie 100: 237-256.

Sabol M., Döppes D., Pacher M., Rabeder G., \& Withalm G., 2008 - Cave bears from the Medvedia jaskyna in the Slovensky raj Mountains (Slovakia): preliminary results. Stalactite, 58 (2): 74-77.

Santi G., Rossi M. \& Dellantonio E., 2011 - Ursus spelaeus Rosenmüller, 1794 from the "Buse di Bernardo" (Tesero, Trento Province, Northern Italy): morphometric, morphodynamic and evolutionary frame. Revue de Paléobiologie, 30 (1): 223-249.

Toškan B., 2006 - Cave bear metapodials from Divje babe I (Western Slovenia). Scientific Annals, School of Geology Aristotle University of Thessaloniki (AUTH), 98: $147-158$.

Wild E., Paunovic M., Rabeder G., Steffan I. \& Steier P., 2001 - Age determination of fossil bones from the Vindija Neandertal site in Croatia. Radiocarbon, 43 (2B): 1021-1028.

Toškan B. \& Bona F., 2012 - Body size variability in cave bears from the Southern Alps. Atti $6^{\circ}$ convegno Nazionale di Archeozoologia, San Romano in Garfagnana (Lucca), 6: $47-55$.

Tsoukala E. \& Grandal-d'Anglande A., 2002 - Systeme de mesures sur le squelette d'Ursidae. In: Tillet T. \& Binford, L.R. (Eds.), L'Ours et l'Homme, Actes du colloque d'Auberives-en-Royans, 1997. Etudes et recherche archéologiques de l'Université de Liège, ERAUL, 265-287 p. 
Withalm G., 2001 - Die Evolution der Metapodien in der Höhlenbären-Gruppe (Ursidae, Mammalia). Beiträge zur Paläontologie, 26: 169-249.

Withalm G., 2004 - Analysis of the cave bear metapodial bones from Potočka zijalka (Slovenia). In: Pacher M., Pohar V. \& Rabeder G. (Eds.), Potočka zijalka - palaeontological and archaeological results of the excavation campaigns 1997-2000. Mitteilungen der Kommission für Quartärforschung der Österreichischen Akademie der Wissenschaften, 13: $149-160$.
Withalm G., 2005 - The development of cave bear metapodial bones in the profile of the Vindija Cave (Croatia). Mitteilungen der Kommission für Quartärforschung der Österreichischen Akademie der Wissenschaften, 14: 241-257.

Withalm G., 2011 - Analysis of the cave bear metapodial bones from Ajdouska jama near Krško (Slovenia). In: Pacher M., Pohar V. \& Rabeder G., (Eds.), Ajdouskajama - Palaeontology, zoology and archaeology of Ajdouska jama near Krško. Mitteilungen der Kommission für Quartärforschung der Österreichischen Akademie der Wissenschaften, 20: 65-71. 
